Article

\title{
The Optimal Level of Strictness and Congregational Growth
}

\section{Todd W. Ferguson}

Department of Sociology, Baylor University, One Bear Place \#97326, Waco, TX 76798-7326, USA; E-Mail: todd_ferguson@baylor.edu; Tel.: +1-254-710-1165

Received: 3 June 2014; in revised form: 29 July 2014 / Accepted: 30 July 2014 /

Published: 8 August 2014

\begin{abstract}
Beginning with Kelley's and Iannaccone's foundational studies, scholars have examined how strictness impacts congregational outcomes. This paper seeks to further develop the strict church thesis by examining Iannaccone's concept of "optimal level of strictness", an idea that there are limits to strictness. Using Stark and Finke's theoretical framework of religious niches and data from the 2005 Baylor Religion Survey and the 2000 Faith Communities Today survey, I find that only prohibitions that are in line with a congregation's religious niche have an impact on growth. To be beneficial, prohibitions must match the pool of potential members' preferences.
\end{abstract}

Keywords: strict church thesis; congregational growth; niches; religious organizations; Protestant Christianity; quantitative methodology

\section{Introduction}

In the 1960s and early 1970s Liberal and Moderate Protestants were struggling to find a reason why their churches were declining in numbers. For much of the history of the United States, Presbyterians, Methodists, Episcopalians, and Congregationalists were at the center of American religious life. Yet, in the mid-twentieth century, these denominations found their churches losing members and losing prominence. At the same time, churches in conservative denominations, such as the Church of the Nazarene, the Southern Baptist Convention, and the Assemblies of God, were growing both in number and in their percentages of the total population. To help understand this change, Dean Kelley, a researcher with the National Council of Churches, proposed the strict church thesis. Going against the predominant assumption that modern individuals would gravitate toward an open-minded and tolerant religion, Kelley put forward the opposite. Strict congregations-those with more rules and more 
exclusive claims - are stronger because they are better than the more lenient churches at offering meaning for their members [1].

Laurence Iannaccone [2] furthered Kelley's theory by incorporating economic mechanisms to Kelley's cultural argument. He defines strictness as "the degree to which a group limits and thereby increases the cost of nongroup activities" ([2], p. 1182, emphasis in original). Religious groups vary in the ways they create strictness, and this diversity can be seen in how Seventh Day Adventists avoid eating meat, Orthodox Jews wear side curls and yarmulkes, and Jehovah's Witnesses reject blood transfusions. Iannaccone suggested the reason why strict congregations are strong is because they reduce the problem of free-riders. Religion can be viewed as a commodity that is produced with others in community. The satisfaction an individual derives from religious practice depends on the quality that others produce. Free-riders are those who do not add anything to the collective religious product but nevertheless reap its benefits. Free-riders, therefore, lower the benefits-per-individual in the congregation. Strict congregations reduce free-riders because they raise the cost of participation. These churches "penalize or prohibit alternative activities that compete for members' resources" ([2], p. 1187, emphasis in original). These prohibitions serve as entry fees for participation and screen out members who might not fully add to the collective religious product. Consequently, strict congregations have fewer free-riders, have higher benefits-per-individual, and experience more congregational strength.

Although Kelley's [1] original book was titled "Why Conservative Churches Are Growing”, neither Kelley nor Iannaccone [2] focused on congregational growth. Growth was only a by-product of strength. Yet further research has shown that strictness and congregational growth are indeed linked. Iannaccone, Olson, and Stark [3] use the theoretical framework of resource mobilization to understand the connection between strictness and growth. Religious congregations can grow only if they have a surplus of resources, specifically time and money. Strict congregations are better able to have surpluses of time because they restrict their members from engaging in alternative activities [2]. These members are more likely to focus on congregational activities because they have few other options. Similarly, these congregations often limit where members can spend money, and so there is more likely to be a surplus of financial resources. Strict congregations are better able to accumulate surpluses of time and money and therefore are more likely to grow. Thomas and Olson [4] confirm this finding that, even when accounting for fertility, congregational strictness significantly and positively affects growth.

Yet are there circumstances where strictness and congregational outcomes are not linked together? Kelley proposed that there are no limits to strictness; he states, "strong organizations are strict...the stricter the stronger" ([1], p. 95). Yet Iannaccone disagrees. Strictness "displays diminishing returns" ([2], p. 1201). There is a point in which an increased level of strictness will not see an accompanying level of either strength or growth. This is the "optimal level of strictness", which is based upon the characteristics of the congregants ([2], p. 1202). Going beyond the optimal level of strictness means that religious groups may build strictness around behaviors or attitudes that do not match the congregants' preferences. Congregants perceive these prohibitions as excessive, which inhibits growth. Therefore, strictness must be at its optimal level in order to affect congregational growth. This paper seeks to further the strict church research by examining the optimal level of strictness for congregations. I use the theoretical framework of niches to understand when the diminishing returns of strictness occur. 


\section{Religious Niches}

The optimal level of strictness corresponds to the preferences of the individuals within congregations. Individual members are the most important resource for religious organizations [5-8], ${ }^{1}$ and they vary in their demand for religious goods and services, or their preferences $[11,12]$. Some prefer very strict religious organizations, while others lean toward more liberal congregations. Thus, individuals may be grouped into theoretical categories, or religious niches, based on their preferences for strictness. A religious niche is the "market segment of potential adherents sharing particular religious preferences (needs, tastes, and expectations)" ([12], p. 195). ${ }^{2}$ Figure 1 shows Stark and Finke's [12] conceptualization of religious niches based on individual preferences for strictness. A major assumption is that these niches are stable over time because the demand for various levels of religious strictness is constant within the population ([14], p. 5). As shown in Figure 1, this assumed distribution of preferences may be thought of as a normal curve, with most of the population desiring some level of strictness that is neither too lenient nor too severe. This does not imply that individual preferences are nonmalleable. Individual preferences are culturally shaped and therefore, changeable. However, at the aggregate, preferences are assumed to follow a normal distribution.

Congregations and their denominations form around these niche categories to serve the religious demand [7]. Thus, they compete for resources, i.e., members $[6,8,13,15]$. It would seem to follow that if a congregation's level of strictness does not match the individuals' preferences within a given niche, the congregation would necessarily recruit members from another niche. Yet the nature of congregations complicates this view. Congregations are more nuanced than aggregations of individuals that compete for potential resources [16]. They are "instantiations of larger institutions" ([5], p. 207). They are carriers of denominational culture, which shapes a congregation's level of strictness. Denominations are associated with certain levels of strictness, even though they exhibit considerable amount of internal diversity within themselves $[12,15,17]$.

These denominational assumptions of strictness are, in turn, ascribed to the congregations. Even non-denominational congregations that do not formally connect with a group are still subject to prevailing expectations associated with larger religious traditions, most notably Conservative Protestantism. Thus, congregations are not entirely free to respond to the religious marketplace's demands from individuals. Many are constrained by their denominational culture and its assumed level of strictness.

Religious traditions are a useful way to represent niches within the American landscape. These are broader groupings of denominations that have similar beliefs, practices, and histories [18-20]. Their constituents have similar preferences in matters of strictness [12]. Though the division is contested, I follow Roof and McKinney [21] to categorize religious groups into eight religious traditions in the United States: Catholics, Jews, Conservative Protestants, Moderate Protestants, Liberal Protestants,

1 Individual members are the constituent resource for religious organizations because they not only are the suppliers of time and money that influence congregational growth [3], but they also impact ritual density, an important factor in sustaining religious communities $[9,10]$.

2 This is a slightly different understanding of niche than Popielarz and Neal ([13], p. 68), which they say is "the set of environmental states in which [a species] needs to survive." In this present study, niches are built around individual preferences, following Stark and Finke [12]. The definitions are most similar at the organizational level, since members, which are organized around preferences, are considered the resources necessary for congregational survival. 
Black Protestants, Other religious groups, and "Nones" (those without religious affiliation) but see $[18,19]$. While religious traditions are not entirely coterminous with niches in the American landscape, this categorization of religious groups as representing niches is useful and easily accessible.

Figure 1. Religious Niches. Source: Stark and Finke [12].

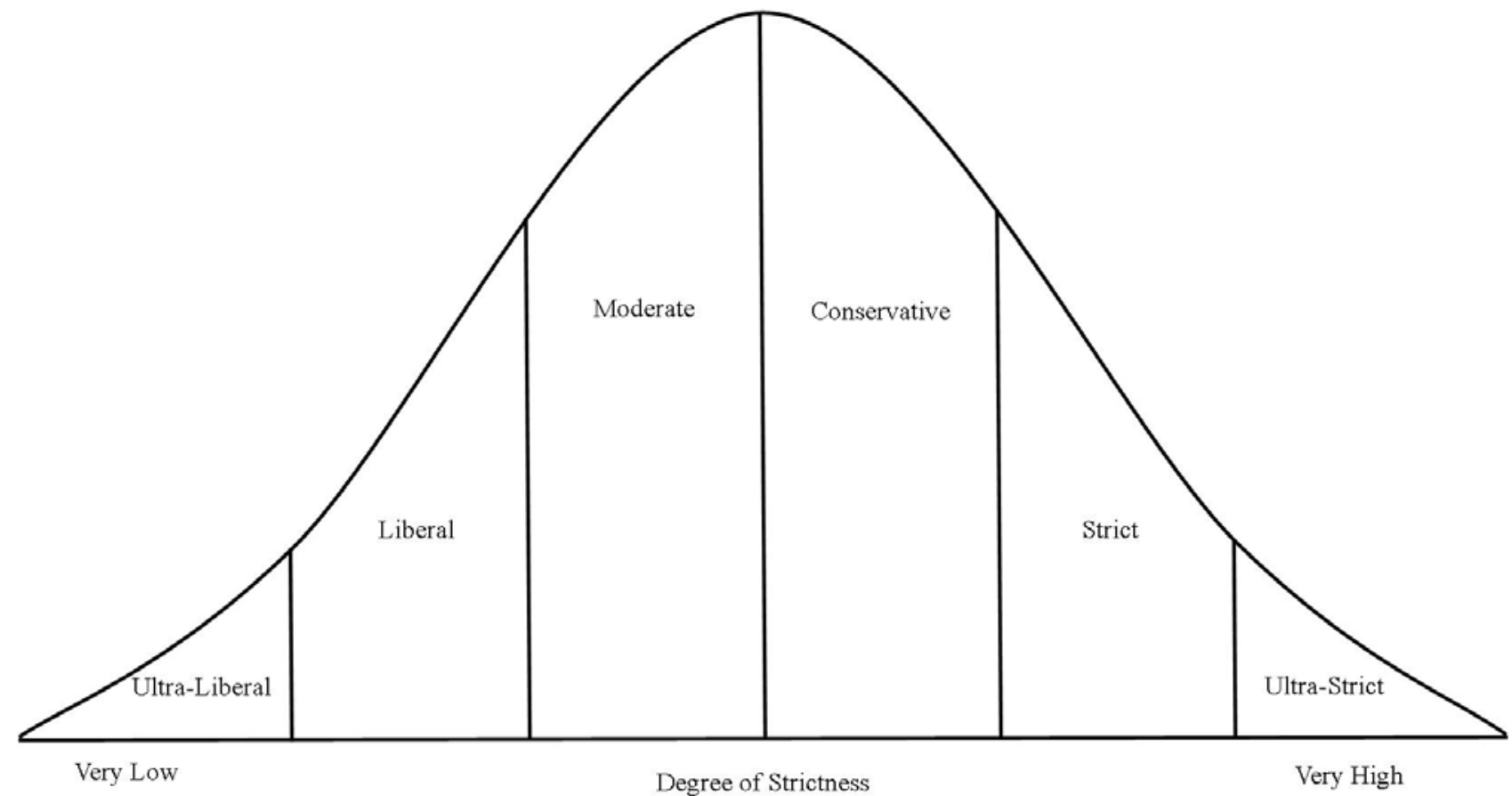

(C) 2000 by the Regents of the University of California. Obtained by permission.

The first two traditions are eponymous, as these groups consist of all Catholic and Jewish groups. Protestants fall into four groups. The Conservative Protestant tradition is comprised of groups that are more sect-like, which emphasize Biblical authority, missionary activity, and individual conversion [20,22,23]. The Liberal Protestant tradition focuses more on "an accommodating stance toward modernity, a proactive view on issues of social and economic justice, and pluralism in their tolerance of varied individual beliefs" ([19], pp. 293-94). Moderate Protestants fall in between these two, as these denominations have congregations that lean toward both of these categories [21]. Black Protestants are the groups that have been shaped by the African-American experience [24]. "Other religious groups" consist of Jehovah's Witnesses, Latter-Day Saints (Mormons), Buddhists, Hindus, and Muslims. Religious "nones" are a growing category which scholars see as an emerging, distinct group [25-28].

\section{Religious Niches and Congregational Growth}

In order for a congregation to grow, it must gain new members. Potential members are most likely to come from within the congregation's religious niche and not from another niche. This is because people are less likely to move out of their current religious tradition and join a congregation in another [11]. Most people join religious congregations that are very similar to their previous one or match their desired level of preference [12]. There is a "homophily of preferences", and so individuals retain as much religious capital as they can by choosing a new congregation ([12], p. 195). A move to 
another religious niche would cost too much religious capital, and so individuals usually stay within congregations that are similar in strictness. As a result, the pool from which congregations draw potential members is most likely the congregation's very own religious niche.

Therefore, it is possible that a congregation's level of strictness could be suboptimal if it is disconnected from its own religious niche. That is, there could be a mismatch between potential members' preferences for strictness and the congregation's own practices. When a congregation's level of strictness is outside the preferences of potential members, then growth is less likely to occur because the congregation is less likely to be attractive within its religious niche. Based on this, I offer the following hypothesis: Strictness increases the likelihood of congregational growth when it is in line with the preferences of the individuals within the congregation's niche.

\section{Testing the Hypothesis}

The relationship between strictness and congregational growth is contingent upon the preferences of those within a religious niche. In order to test this hypothesis, I follow a two-step process. First, I ascertain how people within religious traditions vary in their preferences on an issue of strictness. In essence, I am mapping the contours of religious niches for a specific issue of strictness. Second, I test to see if these preferences affect the relationship between strictness and congregational growth.

For this present study, I examine three religious traditions within American Protestantism (Conservative, Moderate, and Liberal Protestants) and their preferences regarding two historically important issues: alcohol and premarital sex. Protestants do not hold a single view on these two subjects. Their preferences vary, which create distinct religious niches indicating different levels of desired strictness. This offers a useful basis to test the relationship between religious niches and strictness.

\section{Religious Niches for Alcohol and Premarital Sex}

Following the end of the Civil War, many Protestants, especially Methodists and Baptists, turned their attentions to reforming the misuse of alcohol [29]. They created temperance movements across the country and succeeded in pushing for the Eighteenth Amendment to the Constitution which prohibited alcohol in the United States. Although the Twenty-first Amendment overturned the Eighteenth, the trajectory initiated by the temperance movement still remains in much of American Protestant life. Protestant religious beliefs about alcohol are changing, but there continues to be a wide variation within these beliefs. Some Protestants consider all alcohol use to be wrong, although others do not think drinking alcohol is an issue [30].

In order to examine strictness preferences within religious niches, I use the 2005 Baylor Religion Survey (BRS), which is a useful data set to determine how individuals view alcohol. This survey is a national random sample of 1721 individuals in the contiguous United States which the Gallup Organization administered using a mixed-mode method in October and November 2005. Bader, Mencken, and Froese [31] outline the full methodological information. Others have used this survey successfully to understand how various religious groups differ in their views of moral issues [32]. For this study, I examine whether individuals within a religious tradition have significantly different preferences about an issue when compared with those without a religious tradition. This allows me to 
estimate the boundaries of the religious niche in terms of a single issue of strictness. Others have used a similar method with national surveys of individuals to outline religious niches [8].

Figure 2 shows how Americans in three Protestant traditions-Liberal, Moderate, and Conservative 3 - compare with Americans with no religious affiliation when answering the following question on the BRS: "How do you feel about the consumption of alcohol?" Individuals could respond (4) Always wrong, (3) Almost always wrong, (2) Only wrong sometimes, and (1) Not wrong at all. Following conventional niche measurements, the mean responses plus or minus 0.75 standard deviation are displayed $[6,8]$. Although the responses for each religious tradition show both diversity within and niche overlap between traditions, a post-hoc analysis of an ANOVA test using Scheffé's method reveals that Conservative and Moderate Protestants hold significantly different views than individuals without religious affiliation on alcohol consumption, thus indicating different religious niches. Stated differently, the potential members for Conservative and Moderate Protestant churches are located within religious niches that desire some level of strictness surrounding alcohol. Liberal Protestants, however, are not significantly different than those without religious affiliation, indicating that those within this religious tradition do not prefer strictness on this issue. They are located within a religious niche for which alcohol is not an issue.

Premarital sex is also another relevant issue for American Protestants. Traditional Christian teaching has placed sexual activity within the confines of heterosexual marriage. However these boundaries have been challenged beginning in the late 1960s with the sexual revolution. Figure 3 shows how individuals without religious affiliation and Protestants from Liberal, Moderate, and Conservative denominations answered the following question from the 2005 Baylor Religion Survey: "How do you feel about sexual relations before marriage?"

Figure 3 shows the ordering of the groups' beliefs about premarital sex is the same as alcohol. The average responses for people without religious affiliation and Liberal Protestants are lower than Moderate Protestants, who in turn, are lower than Conservative Protestants. The difference between beliefs about alcohol and premarital sex, however, is that all three religious groups-Liberal, Moderate, and Conservative Protestants - are significantly more likely to classify premarital sex as wrong, than those without religious affiliation. Therefore, each tradition is within a religious niche that prefers some strictness surrounding the issue of premarital sex.

To summarize the first step for testing the hypothesis, individuals within all three Protestant traditions have preferences for strictness surrounding premarital sex when compared to those without a religious affiliation. They are within religious niches that prefer strictness for premarital sex. On the other hand, only Moderate and Conservative Protestants have distinct preferences for strictness

\footnotetext{
I created religious tradition categories to match the religious traditions in the Faith Communities Today (FACT) survey, which will be used in the analysis below [33]. For BRS data, Liberal Protestants $(n=173)$ are Congregational, Episcopal/Anglican, Presbyterian, Unitarian Universalists, and United Church of Christ. Moderate Protestants $(n=273)$ are: American Baptists, Disciples of Christ, Evangelical Lutheran Church of America, Mennonite, United Methodist, and Reformed Church of America/Dutch Reformed. Conservative Protestants $(n=393)$ are Assemblies of God, Southern Baptist, Christian Reformed, Church of Christ, Church of the Nazarene, Seventh-day Adventist, and Non-denominational Christian. There are 192 respondents without religious affiliation. I had to omit Black Protestants from analysis because FACT data did not contain the necessary variables for this religious tradition.
} 
surrounding the issue of alcohol. Thus, those within the religious niche for Liberal Protestants do not desire strictness for this issue.

Figure 2. Individual Views on the Consumption of Alcohol (Means of responses \pm 0.75 standard deviation). All differences are significant at the 0.05 level except No AffiliationLiberal Protestants and Liberal Protestants-Moderate Protestants.

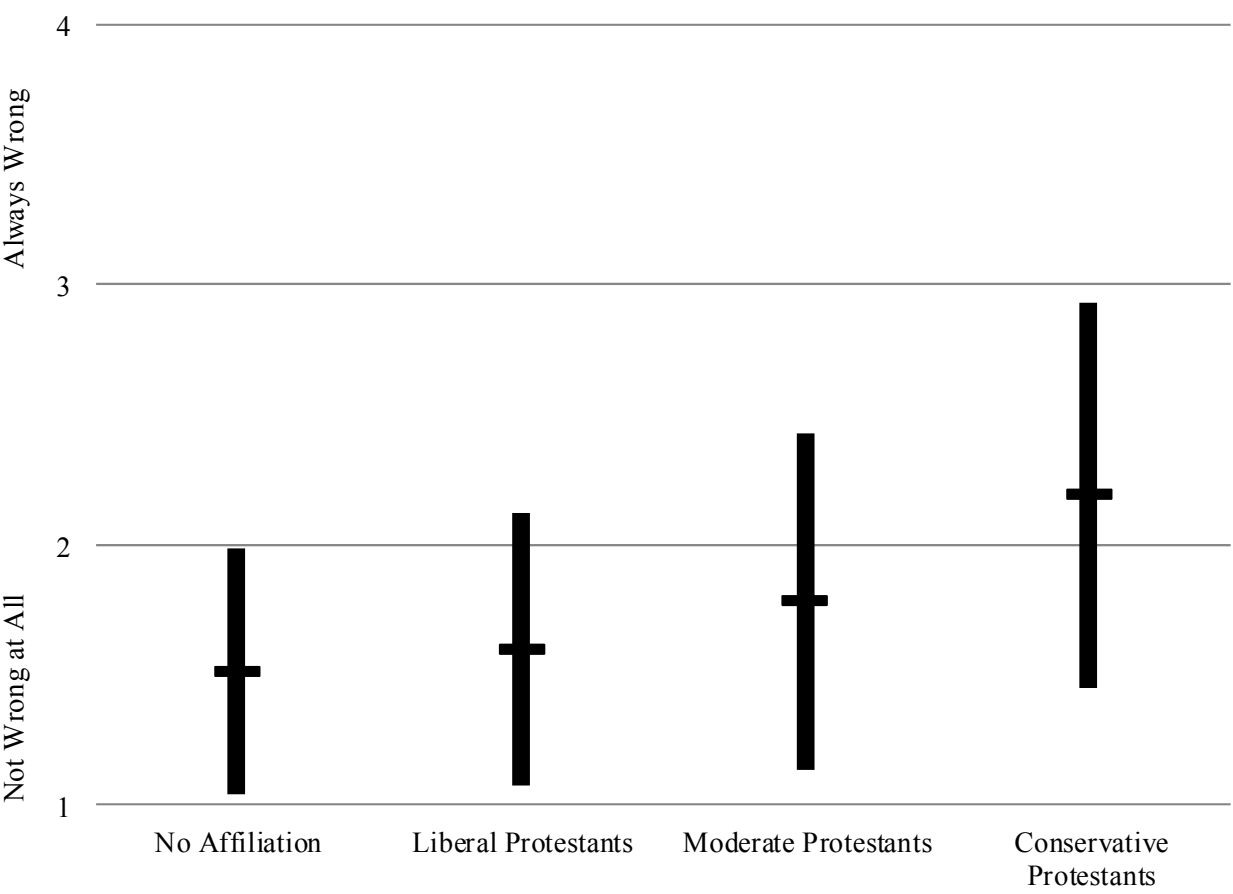

Source: Baylor Religion Survey, 2005.

Figure 3. Individual views on Premarital Sex (Means of responses \pm 0.75 standard deviation). All differences are significant at the 0.05 level.

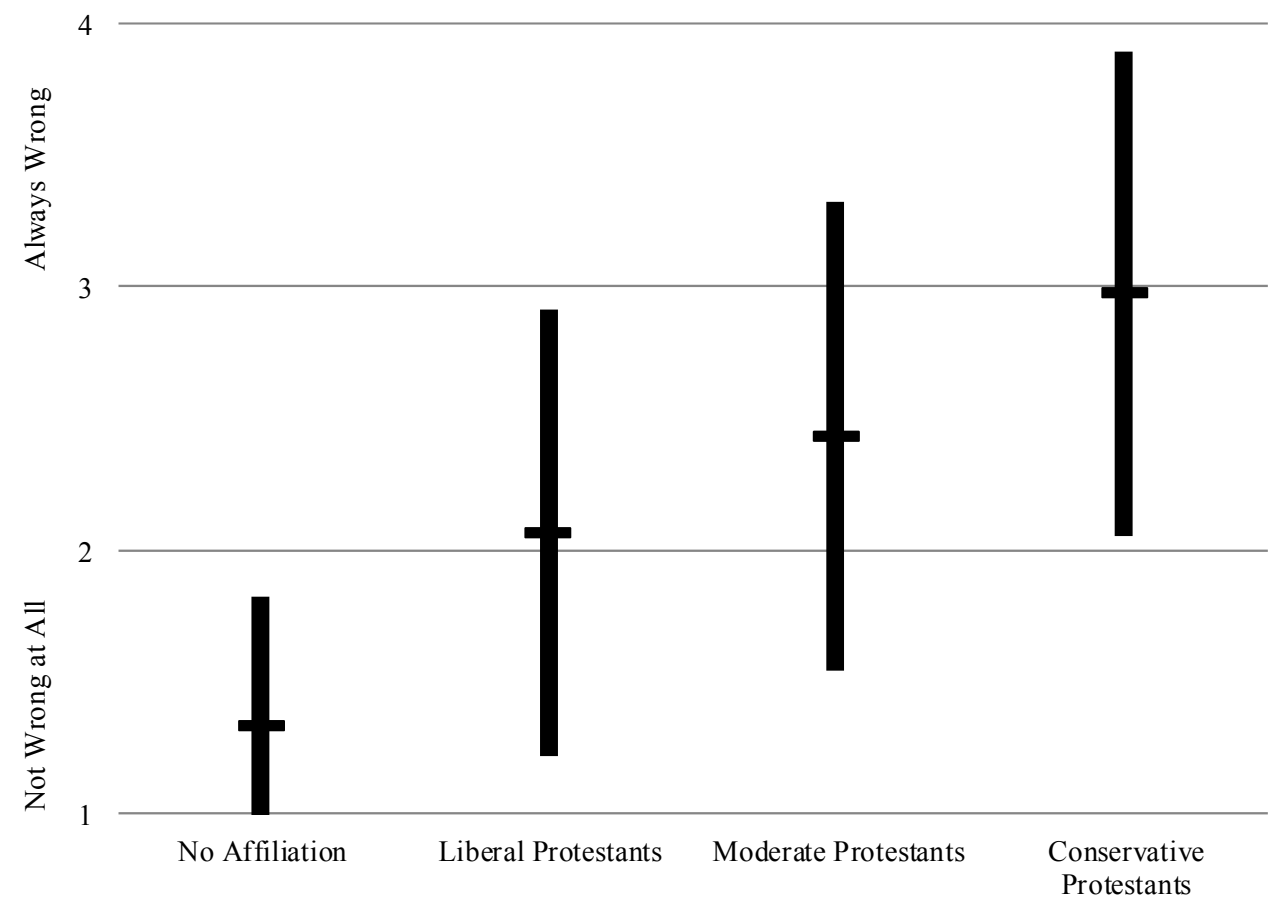

Source: Baylor Religion Survey, 2005. 


\section{Testing Optimal Strictness}

The next step in testing my hypothesis is to see if there is an optimal level of strictness for congregations and growth. In other words, my goal is to see if the relationship between strictness and growth continues in circumstances when the religious preferences of a congregation's potential members (its religious niche) do not line up with congregational practices.

To do this, I use the Faith Communities Today (FACT) survey from 2000, which I obtained from the Association of Religion Data Archives [34]. Coordinated by the Hartford Institute for Religion Research, this survey is the largest study ever conducted on congregations in the United States [33]. FACT data represent 41 denominations and faith groups. Each faith group's survey included core questions on six areas of congregational life and structure: worship, location, programs, leadership, participants, and finances. An informed respondent, usually the senior clergy person, filled out the survey. The survey response rate for the denominations averaged just over 50 percent. A total of 14,301 congregations completed surveys.

FACT divides religious congregations into six categories similar to Roof and McKinney's [21] categories: Liberal Protestant, Moderate Protestant, Conservative Protestant, Historically Black, Catholic/Orthodox and Other. Because of the limited nature of the congregational discourses used to create measures of strictness (discussed below), I remove the Catholic/Orthodox and Other categories from the sample. Furthermore, the survey instrument for Historically Black Protestant congregations unfortunately did not contain many of this study's variables. Therefore, I restrict my analysis to Liberal, Moderate, and Conservative Protestants. Liberal Protestants are Episcopal Church USA, Presbyterian Church USA, Unitarian-Universalist, and the United Church of Christ. There are 2565 Liberal Protestant responses. Moderate Protestants are American Baptist Churches, Disciples of Christ, Evangelical Lutheran Church in American, Mennonite, Reformed Church in America, and the United Methodist Church. There are 3263 Moderate Protestant congregations in the study. Conservative Protestants are Assemblies of God, Christian Reformed Church, Church of the Nazarene, Churches of Christ, Independent Christian Churches (Instrumental), Mega-churches, Nondenominational Protestant, Seventh-day Adventist, and the Southern Baptist Convention. There are 3610 Conservative Protestant responses. The FACT 2000 public data file from the Association of Data Religion Archives did not include a denomination variable. Therefore, I am forced to use categories described above.

FACT data are useful to test my hypothesis. First, these data are from a very broad sample. While not all faith groups in the U.S. participated, most of the largest denominations are included. Because of this breadth, FACT represents $80 \%$ of all U.S. congregations [33]. Second, FACT is a survey of some depth. Each congregation reported on church growth, how much they address social issues, how active they are at outreach, and the demographics of the congregants. In addition to the congregational questions, FACT includes United States Census data at the ZIP code level for 1980, 1990, and 2000. This allows me to control for the surrounding ecological influences for each congregation that might influence growth, such as a growing community population.

Third, this analysis requires a high number of responses from Liberal Protestant congregations who have either anti-alcohol or anti-sex discourses, which is not possible with the other national congregational surveys, such as the National Congregations Study and the U.S. Congregational Life Survey. 


\subsection{Dependent Variable: Congregational Growth}

To measure congregational growth, FACT asked each congregation, "Since 1995, has the number of regularly participating adults: Decreased 10\% or more; Decreased 5\% to 9\%; Stayed about the same (plus or minus $4 \%$ ); Increased $5 \%$ to $9 \%$; Increased $10 \%$ or more?" I create a binary church growth variable for (1) congregational growth of $5 \%$ or more and (0) congregational stability or decline. The appendix shows the descriptive statistics for each variable.

\subsection{Independent Variable: Congregational Discourse on Alcohol Use and Premarital Sex}

Congregational strictness is measured by the level of discourse surrounding alcohol use and premarital sex within a church. The FACT survey asked, "How much does your congregation, in its worship and education, emphasize the following home and personal practices?" Practices included personal prayer, family devotions, fasting, observing a special diet, abstaining from alcohol, observing a weekly holy day, displaying icons, and abstaining from premarital sex. I focus on abstaining from alcohol and premarital sex because of their relevance to American Protestants. Each congregation could respond "Not at all", "A little", "Some", Quite a bit", or "A great deal". Tables 1 and 2 show how congregations in each Protestant tradition responded. The distributions of anti-alcohol and premarital sex discourses within congregations mirror the individual responses to these prohibitions. Conservative Protestant churches are the most likely to actively emphasize anti-alcohol and premarital sex messages. Liberal Protestant churches are the least likely.

Table 1. Congregational Discourse on Abstaining from Alcohol.

\begin{tabular}{|c|c|c|c|c|c|c|}
\hline \multirow[b]{2}{*}{ Amount } & \multicolumn{2}{|c|}{$\begin{array}{c}\text { Liberal } \\
\text { Protestant }\end{array}$} & \multicolumn{2}{|c|}{$\begin{array}{l}\text { Moderate } \\
\text { Protestant }\end{array}$} & \multicolumn{2}{|c|}{$\begin{array}{c}\text { Conservative } \\
\text { Protestant }\end{array}$} \\
\hline & $\%$ & $n$ & $\%$ & $n$ & $\%$ & $n$ \\
\hline Not At All or A Little & 88.4 & 2219 & 62.1 & 1985 & 28.3 & 1005 \\
\hline Some & 8.8 & 222 & 20.5 & 655 & 23.1 & 820 \\
\hline Quite a Bit or A Great Deal & 2.8 & 69 & 17.5 & 558 & 48.5 & 1721 \\
\hline Total & 100 & 2510 & 100 & 3198 & 100 & 3546 \\
\hline
\end{tabular}

Source: Faith Communities Today (2000). Totals do not equal exactly $100 \%$ due to rounding.

Table 2. Congregational Discourse on Abstaining from Premarital Sex.

\begin{tabular}{lccccccccc}
\hline & \multicolumn{2}{c}{$\begin{array}{c}\text { Liberal } \\
\text { Protestant }\end{array}$} & & \multicolumn{2}{c}{$\begin{array}{c}\text { Moderate } \\
\text { Protestant }\end{array}$} & & \multicolumn{2}{c}{$\begin{array}{c}\text { Conservative } \\
\text { Protestant }\end{array}$} \\
\cline { 2 - 3 } Amount & $\%$ & $n$ & & $\%$ & $n$ & & $\%$ & $n$ \\
\hline Not At All or A Little & 62.9 & 1574 & & 28.3 & 908 & & 8.2 & 292 \\
Some & 21.9 & 549 & & 30.1 & 965 & & 19.7 & 702 \\
Quite a Bit or A Great Deal & 15.2 & 379 & & 41.6 & 1334 & & 72.1 & 2566 \\
Total & 100 & 2502 & & 100 & 3207 & & 100 & 3560 \\
\hline
\end{tabular}

Source: Faith Communities Today (2000). Totals do not equal exactly $100 \%$ due to rounding. 
In the analysis that follows, I create binary, prohibition discourse variables for anti-alcohol and anti-premarital sex to measure congregational emphases on these two behavior issues. Coding is (1) Congregations that emphasize the topic "Quite a bit" or "A great deal" and (0) congregations that emphasize the topic at the other levels.

\subsection{Congregational Control Variables}

I control for other congregational factors that might contribute to church growth. The age of a church is held constant by using the year founded. Congregation size is measured by the natural logarithm of the number of adults (18 years and older) who regularly participate in religious life at the congregation, whether or not they are members. I also control for the demographics of a church by holding constant the percentage of younger adults (under 35), older adults (over 60), and females participating in church life. These three variables range from 1 to 7 with the responses being (1) None $0 \%$, (2) Hardly any $1 \%-10 \%$, (3) Few $11 \%-20 \%$, (4) Some $21 \%-40 \%$, (5) Many $41 \%-60 \%$, (6) Most $61 \%-80 \%$, and (7) All or nearly all $81 \%-100 \%$. Because the responses 1 through 7 are not meaningful as a numeric scale, I use the midpoints of each response $(0,5,15,30,50,70$, and 90$)$ to create interval variables.

I also control for congregational outreach activities. The FACT survey asked: "In addition to the outreach activities of your denomination, did your congregation do any of the following during the past 12 months to reach out to new or inactive participants, or to make your congregation better known in your community?" I control for three types of marketing approaches: newspaper ads, radio and television ads, and direct mail promotions. Each of these is a binary variable: (1) Yes, done in the last 12 months and (0) No.

\subsection{Community Control Variables}

In addition to the internal factors within a congregation, I also control for a congregation's surrounding community. I control for ZIP-code population in 2000 (natural logarithmic transformed) and the percentage change in ZIP-code population from 1990 to 2000. This variable is a discrete, 1 percent interval measure of the percentage change (e.g., $-12 \%$ or $5 \%$ ). The upper and lower ranges are capped off at " $-20 \%$ or lower" and " $30 \%$ or higher" (coded as -20 and 30 , respectively). Finally, region of the country is held constant by a series of binary variables, with South as the comparison group.

\section{Method}

Binary logistic regression is the most appropriate method because the dependent variable of church growth is dichotomous. Because of the high correlation between anti-alcohol and anti-premarital sex discourses $(r=0.52)$, I separate these independent variables in the models. I estimate six models, separating the three Protestant traditions by how anti-alcohol or anti-premarital sex discourses affect church growth. ${ }^{4}$ I expect significant positive estimates for the relationship between growth and a congregation's strictness on an issue for religious traditions whose pool of potential members have

4 I also estimated the models using an OLS regression. I used $0.10,0.07,0.00,-0.07$, and -0.10 for the measurement of congregational growth. The results were the same as the binary logistic regression. The tables are available upon request. 
distinct strictness preferences (e.g., the issue of alcohol for Conservative Protestants or premarital sex for Liberal Protestants). On the other hand, I expect non-significant estimates for the relationship between congregational growth and an issue of strictness when a religious tradition's potential members do not have preferences of strictness that are distinct from the unaffiliated.

\section{Results}

Table 3 shows the results from six binary logistic regressions predicting a congregation growing 5\% or more. As hypothesized, only the congregational discourses about strictness that match its niche's preferences are the ones that are associated with increased odds of being a growing congregation, while the one that does not match does not affect the likelihood of growth.

Models 1, 3, and 5 show anti-alcohol discourse affects the probability of congregational growth in both Moderate and Conservative Protestant churches, but not in Liberal Protestants congregations. Liberal churches that actively emphasize anti-alcohol messages are no more likely to grow than those who do not maintain this prohibition. By comparison, Conservative churches with high levels of anti-alcohol discourse are $73 \%$ more likely to grow, and Moderates with the same level are 55\% more likely.

Other congregational characteristics also affect church growth. Churches founded more recently and larger congregations (i.e., those with more regularly participating adults) are more likely to grow. Churches from all traditions with higher percentages of older adults have lower odds of growth, as do Liberal and Moderate Protestant congregations with more females. Advertising through radio, television, and mail outs only affects growth for Conservative congregations. Liberal and Conservative churches in areas with greater ZIP populations have lower odds of growth, but a growing ZIP code population increases the odds for all three traditions. Liberal and Conservative churches in the Midwest are less likely to grow compared to Southern Liberals and Conservatives.

Unlike anti-alcohol discourse, which did not affect congregational growth in all traditions, anti-premarital sex discourse does. Models 2, 4, and 6 in Table 3 show Liberal, Moderate, and Conservative Protestant congregations that have high levels of anti-premarital sex discourse are 55\%, $34 \%$, and $54 \%$ more likely to grow, respectively. Like the other models, newer churches and larger churches are more likely to be growing, while the percentage of older adults lowers the odds of growth for all three traditions. The percentage female only lowers the odds of growth in Liberal Protestant congregations.

The gender ratio has no effect in Moderate and Conservative churches in these models. Advertising through radio, television, and the mail increases the odds of growth in Conservative congregations, but has no effect for Moderates and Liberals. Community variables also affect the odds of congregational growth. Liberal and Conservative Protestant churches in ZIP codes with large populations have lower odds of growth. ZIP code population does not make a difference for Moderate congregations. However, the growth in congregational ZIP codes does affect the odds for all three traditions. For each percentage increase in ZIP code population change, the odds that a church is growing increase by either $1 \%$ or $2 \%$. Finally, congregations in all traditions are less likely to grow if they are located in the Midwest as compared to the South. 
Table 3. Binary Logistic Regressions Predicting Congregations Growing 5\% or More (Odds Ratios Shown).

\begin{tabular}{|c|c|c|c|c|c|c|}
\hline \multirow[b]{2}{*}{ Variables } & \multicolumn{2}{|c|}{ Liberal Protestant } & \multicolumn{2}{|c|}{ Moderate Protestant } & \multicolumn{2}{|c|}{ Conservative Protestant } \\
\hline & Model 1 & Model 2 & Model 3 & Model 4 & Model 5 & Model 6 \\
\hline \multicolumn{7}{|l|}{ Prohibition Discourse } \\
\hline Anti-Alcohol & 1.36 & - & $1.55 * * *$ & - & $1.73 * * *$ & - \\
\hline Anti-Premarital Sex & - & $1.55 * *$ & - & $1.34 * * *$ & - & $1.54 * * *$ \\
\hline \multicolumn{7}{|l|}{ Congregational Variables } \\
\hline Year Organized & $1.00 * *$ & $1.00 * *$ & $1.00 * *$ & $1.00 * *$ & $1.01 * * *$ & $1.01 * * *$ \\
\hline \# Regular Adults (Log) & $1.97 * * *$ & $1.93 * * *$ & $1.36 * * *$ & $1.34 * * *$ & $1.68 * * *$ & $1.58 * * *$ \\
\hline$\%$ Young Adults & 1.00 & 1.00 & 1.00 & 1.00 & 1.00 & 1.00 \\
\hline$\%$ Older Adults & $0.98 * * *$ & $0.98 * * *$ & $0.99 * * *$ & $0.99 * * *$ & $0.99 * * *$ & $0.99 * * *$ \\
\hline$\%$ Female & $0.98 * * *$ & $0.98 * * *$ & $0.99 *$ & 0.99 & 1.00 & 1.00 \\
\hline Newspaper Ads & 1.08 & 1.09 & 1.02 & 1.02 & 0.95 & 0.93 \\
\hline Radio/TV Ads & 1.17 & 1.15 & 1.17 & 1.15 & $1.25 *$ & $1.31 * *$ \\
\hline Mailout Ads & 1.23 & 1.21 & 1.13 & 1.13 & $1.28 *$ & $1.29 * *$ \\
\hline \multicolumn{7}{|l|}{ Community Variables } \\
\hline ZIP Population (Log) & $0.84 * * *$ & $0.84 * * *$ & 1.04 & 1.04 & $0.88 * * *$ & $0.89 * *$ \\
\hline \% ZIP Population Change & $1.02 * * *$ & $1.02 * * *$ & $1.02 * * *$ & $1.02 * * *$ & $1.01 * * *$ & $1.01 * *$ \\
\hline \multicolumn{7}{|l|}{ Region } \\
\hline South & Reference & Reference & Reference & Reference & Reference & Reference \\
\hline North & 0.92 & 0.939 & 1.11 & 1.09 & 1.24 & 1.21 \\
\hline Midwest & $0.58 * * *$ & $0.58 * * *$ & 0.79 & $0.77 *$ & $0.80 *$ & $0.76 * *$ \\
\hline West & 1.01 & 1.035 & 0.82 & 0.79 & 0.90 & 0.87 \\
\hline $\mathrm{N}$ & 2170 & 2163 & 2535 & 2548 & 3113 & 3119 \\
\hline -2 Log Likelihood & 3007.37 & 2998.11 & 3486.92 & 3504.46 & 4313.10 & 4321.43 \\
\hline Max-rescaled $\mathrm{R}^{2}$ & 0.21 & 0.21 & 0.11 & 0.11 & 0.16 & 0.15 \\
\hline
\end{tabular}




\section{Discussion and Conclusions}

This study seeks to better understand the relationship between congregational strictness and growth. I have done so by showing evidence for the idea that strictness must be in line with the congregation's religious niche, its source of potential members. As others have found before, strictness still matters $[1,2,4,12]$. The boundaries that churches create by establishing rules raise the costs of being a member. These increased costs allow the church to generate higher levels of resources, which in turn increase the chances for growth [3]. Moreover, strictness is not a factor for only Conservative Protestants; it is important across all three Protestant traditions.

More importantly, this study modifies the classic strict church thesis. It helps shed light on what Iannaccone [2] meant by an optimal level of strictness. Strictness is not always associated with congregational growth. That is, a congregation cannot prohibit any behavior and expect this increase in strictness to increase the likelihood of growth. Instead, growth via strictness is contingent upon potential members' preferences for strictness on an issue. This is why the Liberal Protestant congregations that have high levels of anti-alcohol discourse are not more likely to grow.

These churches, by definition, are stricter churches than their fellow Liberal congregations, but this strictness does not affect growth. Those in their religious niche, the greatest source of potential members, do not want a church with rules about drinking. Thus, the costs incurred by prohibiting alcohol are too high for Liberal Protestants. Potential members are unwilling to pay this price of membership because they do not prefer a level of strictness on this issue.

The prohibition of alcohol does affect growth for Moderate and Conservative congregations, though, because the costs incurred are much lower. In fact, this restriction might actually be a benefit because it lines up with the preferences of their religious niches. Therefore, the prohibition of alcohol in these congregations may be viewed as both a cost and a benefit. It is a cost that restricts alternative behavior and frees up other resources conducive for growth, but it also creates a favorable cost-benefit ratio for its potential members by lining up with their niche preferences.

These findings also support the idea that there is a "spiritual marketplace" in American Protestant Christianity [35,36]. Religious niches are essentially constructed around consumer preferences, and congregations market and supply the religious goods to these niches. If a congregation is out of step with its niche (i.e., its practices and discourses used to construct its level of strictness do not match the demands of the religious marketplace), then it will not attract new members from the niche. For this reason, Liberal Protestant churches who emphasized not drinking alcohol were not likely to be growing congregations.

This study has some limitations. FACT is not a random sample of congregations throughout the United States. Instead, it is a very broad survey of participating faith groups. Positively, this means that the number of congregations and denominations in this study is quite high [37]. Negatively, it means that, while strongly suggestive of how strictness works within congregations, these findings are not nationally representative of all American Protestant churches.

The main drawback of the 2000 FACT survey is its limited scope. The survey asked about only two prohibitive discourses that are salient for Protestant Christians in the United States: alcohol and premarital sex. These are by no means the only relevant issues for Protestants, and Protestantism is by no means the only religious tradition. This study could be strengthened by examining congregations in 
other countries and looking at other issues, such as theological beliefs, economics, race, gender, or sexuality. It could also be strengthened to see where the line for optimal strictness is in other congregationally-based religious traditions, such as Catholicism, Islam, and Judaism. Furthermore, these findings open up the possibilities to examine how optimal strictness, as delineated by religious niches, impacts congregational strength, the main focus of Kelley [1] and Iannaccone [2].

Future research in the sociology of religion needs to account for the idea that strictness is a multifaceted concept. It does not uniformly affect other congregational outcomes. An organization's niche matters, and the population from which the congregation draws new members responds differently to numerous issues used to create congregational strictness. Scholars continuing to explore the strict church thesis must take this into account when they explore how a religious organization's rules and regulations impact congregational life.

This study advances the classic strict church thesis within the sociology of religion by illuminating what optimal strictness is for congregational growth. Congregational prohibitions do not automatically increase the likelihood of growth. Effective prohibitions are contingent and defined by the congregation's religious niche (i.e., its potential members). By lining up its congregational practices with its religious niche's preferred level of strictness, a congregation increases its chances for growth.

\section{Acknowledgments}

The author would like to thank Kevin Dougherty, Paul Froese, Charles North, and Christopher Pieper for their valuable assistance.

\section{Conflicts of Interest}

The author declares no conflict of interest. 


\section{Appendix}

Descriptive Statistics for Variables.

\begin{tabular}{|c|c|c|c|c|c|c|c|c|c|c|c|c|}
\hline \multirow[b]{2}{*}{ Variables } & \multicolumn{4}{|c|}{ Liberal Protestants } & \multicolumn{4}{|c|}{ Moderate Protestants } & \multicolumn{4}{|c|}{ Conservative Protestants } \\
\hline & $\mathrm{N}$ & Mean & Std Dev & Range & $\mathrm{N}$ & Mean & Std Dev & Range & $\mathrm{N}$ & Mean & Std Dev & Range \\
\hline \multicolumn{13}{|l|}{ Dependent Variable } \\
\hline Growing Church & 2565 & 0.48 & & $0-1$ & 3263 & 0.44 & & $0-1$ & 3610 & 0.51 & & $0-1$ \\
\hline \multicolumn{13}{|l|}{ Independent Variables } \\
\hline Anti-Alcohol & 2510 & 0.03 & & $0-1$ & 3198 & 0.17 & & $0-1$ & 3546 & 0.49 & & $0-1$ \\
\hline Anti-Premarital Sex & 2502 & 0.15 & & $0-1$ & 3207 & 0.42 & & $0-1$ & 3560 & 0.72 & & $0-1$ \\
\hline \multicolumn{13}{|l|}{ Congregational Variables } \\
\hline Year Organized & 2429 & 1897 & 66.52 & $1629-2000$ & 2836 & 1911 & 57.21 & $1642-2000$ & 3504 & 1945 & 38.55 & $1735-2000$ \\
\hline \# Regular Adults (Log) & 2525 & 4.63 & 1.05 & $-0.69-8.85$ & 3219 & 4.52 & 1.18 & $-0.69-8.52$ & 3515 & 4.55 & 1.30 & $-0.69-9.62$ \\
\hline$\%$ Young Adults & 2481 & 33.92 & 19.14 & $0-90$ & 3144 & 34.65 & 18.58 & $0-90$ & 3496 & 36.91 & 17.73 & $0-90$ \\
\hline$\%$ Older Adults & 2523 & 40.55 & 18.28 & $0-70$ & 3158 & 40.32 & 18.19 & $0-70$ & 3508 & 34.95 & 17.48 & $0-70$ \\
\hline$\%$ Female & 2530 & 55.55 & 10.64 & $0-90$ & 3185 & 54.53 & 10.50 & $0-90$ & 3520 & 51.87 & 10.69 & $0-90$ \\
\hline Newspaper Ads & 2565 & 0.78 & & $0-1$ & 3263 & 0.70 & & $0-1$ & 3610 & 0.63 & & $0-1$ \\
\hline Radio/TV Ads & 2565 & 0.17 & & $0-1$ & 3263 & 0.22 & & $0-1$ & 3610 & 0.31 & & $0-1$ \\
\hline Mailout Ads & 2565 & 0.26 & & $0-1$ & 3263 & 0.29 & & $0-1$ & 3610 & 0.35 & & $0-1$ \\
\hline \multicolumn{13}{|l|}{ Community Variables } \\
\hline ZIP Population (Log) & 2435 & 9.57 & 1.10 & $3.40-11.58$ & 3122 & 9.18 & 1.38 & $1.39-11.63$ & 3431 & 9.53 & 1.18 & $2.40-11.56$ \\
\hline \% ZIP Population Change (90-00) & 2435 & 6.99 & 12.05 & $-20-30$ & 3122 & 5.96 & 11.75 & $-20-30$ & 3431 & 10.16 & 12.41 & $-20-30$ \\
\hline North & 2565 & 0.29 & & $0-1$ & 3263 & 0.24 & & $0-1$ & 3610 & 0.07 & & $0-1$ \\
\hline Midwest & 2565 & 0.28 & & $0-1$ & 3263 & 0.45 & & $0-1$ & 3610 & 0.34 & & $0-1$ \\
\hline West & 2565 & 0.15 & & $0-1$ & 3263 & 0.10 & & $0-1$ & 3610 & 0.23 & & $0-1$ \\
\hline South & 2565 & 0.26 & & $0-1$ & 3263 & 0.20 & & $0-1$ & 3610 & 0.34 & & $0-1$ \\
\hline
\end{tabular}

Source: Faith Communities Today (2000). 


\section{References}

1. Kelley, Dean M. Why Conservative Churches Are Growing; A Study in Sociology of Religion. New York: Harper \& Row, 1972.

2. Iannaccone, Laurence R. "Why Strict Churches Are Strong." American Journal of Sociology 99 (1994): 1180.

3. Iannaccone, Laurence R., Daniel V.A. Olson, and Rodney Stark. "Religious Resources and Church Growth." Social Forces 74 (1995): 705-31.

4. Thomas, Jeremy N., and Daniel V.A. Olson. "Testing the Strictness Thesis and Competing Theories of Congregational Growth.” Journal for the Scientific Study of Religion 49 (2010): 619-39.

5. Chaves, Mark. Congregations in America. Cambridge: Harvard University Press, 2004.

6. McPherson, Miller. "An Ecology of Affiliation." American Sociological Review 48 (1983): 519-32.

7. Scheitle, Christopher P., and Kevin D. Dougherty. "The Sociology of Religious Organizations." Sociology Compass 2 (2008): 981-99.

8. Scheitle, Christopher P. "Organizational Niches and Religious Markets: Uniting Two Literatures.” Interdisciplinary Journal of Research on Religion 3 (2007): 1-29.

9. Draper, Scott. "Effervescence and Solidarity in Religious Organizations." Journal for the Scientific Study of Religion 53 (2014): 229-48.

10. Collins, Randall. Interaction Ritual Chains. Princeton: Princeton University Press, 2005.

11. Sherkat, Darren E., and John Wilson. "Preferences, Constraints, and Choices in Religious Markets: An Examination of Religious Switching and Apostasy." Social Forces 73 (1995): 993-1026.

12. Stark, Rodney, and Roger Finke. Acts of Faith: Explaining the Human Side of Religion. Berkeley: University of California Press, 2000.

13. Popielarz, Pamela A., and Zachary P. Neal. "The Niche as a Theoretical Tool." Annual Review of Sociology 33 (2007): 65-84.

14. Becker, Gary S. The Economic Approach to Human Behavior. Chicago: University of Chicago Press, 1976.

15. Reimer, Sam. "Orthodoxy Niches: Diversity in Congregational Orthodoxy Among Three Protestant Denominations in the United States." Journal for the Scientific Study of Religion 50 (2011): 763-79.

16. Goldstein, Adam, and Heather A. Haveman. "Press and Pulpit: Competition, Co-operation and the Growth of Religious Magazines in Antebellum America." American Sociological Review 78 (2013): 797-827.

17. Olson, Daniel V.A., and Paul Perl. "Variations in Strictness and Religious Commitment Within and Among Five Denominations." Journal for the Scientific Study of Religion 40 (2001): 757-64.

18. Smith, Tom W. "Classifying Protestant Denominations." Review of Religious Research 31 (1990): $225-45$.

19. Steensland, Brian, Jerry Z. Park, Mark D. Regnerus, Lynn D. Robinson, W. Bradford Wilcox, and Robert D. Woodberry. "The Measure of American Religion: Toward Improving the State of the Art." Social Forces 79 (2000): 291-318.

20. Wellman, James K. Evangelical vs. Liberal: The Clash of Christian Cultures in the Pacific Northwest. New York: Oxford University Press, 2008. 
21. Roof, Wade Clark, and William McKinney. American Mainline Religion: Its Changing Shape and Future. New Brunswick: Rutgers University Press, 1987.

22. Hunter, James Davison. Evangelicalism: The Coming Generation. Chicago: University of Chicago Press, 1993.

23. Smith, Christian. American Evangelicalism: Embattled and Thriving. Chicago: University of Chicago Press, 1998.

24. Lincoln, C. Eric, and Lawrence H. Mamiya. The Black Church in the African American Experience. Durham: Duke University Press, 1990.

25. Baker, Joseph O'Brian, and Buster Smith. "None Too Simple: Examining Issues of Religious Nonbelief and Nonbelonging in the United States." Journal for the Scientific Study of Religion 48 (2009): 719-33.

26. Baker, Joseph O., and Buster G. Smith. "The Nones: Social Characteristics of the Religiously Unaffiliated." Social Forces 87 (2009): 1251-63.

27. Funk, Cary, and Greg Smith. "Nones" on the Rise: One-in-Five Adults Have No Religious Affiliation. Religion \& Public Life. Washington: Pew Research Center, 2012, p. 80.

28. Kosmin, Barry A., Ariela Keysar, Ryan Cragun, and Juhem Navarro-Rivera. American Nones: The Profile of the No Religion Populations. Hartford: Trinity College, 2008, p. 29.

29. Butler, Jon, Grant Wacker, and Randall Balmer. Religion in American Life: A Short History. New York: Oxford University Press, 2003.

30. Vox, Lisa. "Religion, Influences on Use of Alcohol and Drugs." In Alcohol and Drugs in North America: A Historical Encyclopedia. Edited by David Fahey and Jon S. Miller. Santa Barbara: ABC-CLIO, 2013, pp. 586-93.

31. Bader, Christopher D., F. Carson Mencken, and Paul Froese. "American Piety 2005: Content and Methods of the Baylor Religion Survey." Journal for the Scientific Study of Religion 46 (2007): 447-63.

32. Froese, Paul, and Christopher D. Bader. America's Four Gods: What We Say About God-- \& What That Says About Us. New York: Oxford University Press, 2010.

33. Dudley, Carl S., and David A. Roozen. Faith Communities Today: A Report on Religion in the United States Today. Hartford: Hartford Institute for Religion Research, Hartford Seminary, 2001.

34. "Faith Communities Today." Available online: http://www.thearda.com/Archive/FCT.asp (accessed on 30 July 2014).

35. Roof, Wade Clark. Spiritual Marketplace: Baby Boomers and the Remaking of American Religion. Princeton: Princeton University Press, 1999.

36. Berger, Peter L. The Sacred Canopy: Elements of a Sociological Theory of Religion. New York: Anchor, 1967.

37. Iannaccone, Laurence R. "Reassessing Church Growth: Statistical Pitfalls and Their Consequences.” Journal for the Scientific Study of Religion 35 (1996): 197-216.

(C) 2014 by the author; licensee MDPI, Basel, Switzerland. This article is an open access article distributed under the terms and conditions of the Creative Commons Attribution license (http://creativecommons.org/licenses/by/3.0/). 